\title{
Modification and Performance Evaluation of Thresher for Black Gram
}

\author{
Nishanth M. Stanly ${ }^{1}$, Arun Kumar ${ }^{1}$, Ratnakiran D Wankhade ${ }^{1 *}$, \\ Pankaj Malkani ${ }^{2}$, Annu Rani ${ }^{1}$ and Ekta Sharma ${ }^{1}$ \\ ${ }^{1}$ Department of Farm Machinery and Power Engineering, College of Technology, \\ G.B.P.U.A \& T., Pantnagar, Uttarakhand, India \\ ${ }^{2}$ Department of Farm Power and Equipment, IARI, Pusa, New Delhi, India \\ *Corresponding author
}

\section{A B S T R A C T}

\section{Keywords}

Black gram,

Cylinder speed,

Conclave clearance,

Threshing

Article Info

Accepted:

26 February 2020

Available Online:

10 March 2020
The study was conducted at Department of Farm Machinery and Power Engineering, G.B. Pant University of Agriculture and Technology, Pantnagar. Existing cowpea thresher was modified for black gram threshing in particular to hilly regions. After necessary modification performance evaluation of thresher was carried out on black gram for different cylinder speed $(20 \mathrm{rpm} / 6.19 \mathrm{~m} / \mathrm{s}, 370 \mathrm{rpm} / 7.16 \mathrm{~m} / \mathrm{s}$ and $440 \mathrm{rpm} / 8.52 \mathrm{~m} / \mathrm{s})$ and conclave clearance $(12 \mathrm{~mm}, 15 \mathrm{~mm}, 18 \mathrm{~mm})$. The obtained results showed suitability of modified thresher for hilly regions of Uttarakhand for threshing black gram.

\section{Introduction}

In the Uttarakhand state, out of total 5563147 hectares of reported area, only 762 thousand hectare land is available for agriculture purpose which is $14.24 \%$ of the total area and out of that only $40.66 \%$ area is irrigated. About $88 \%$ of total geographical area of Uttarakhand is under hill and $12 \%$ of in plain region. Also the $76.85 \%$ population lives in the rural areas where agriculture continues to be the main stay of the hill people. Urad has been promoted in hills as well as in the plain regions of Uttarakhand. A considerable area is covered by pulse crops. They are fast grown and short duration crops. Since the turnaround time between the crops is very less, it becomes essential that the crops are threshed timely. The transportation of large machineries to the hills is very difficult due to high slope. The scarcity of machinery and non-availability of small size machinery makes the job difficult in hills. For pulses there is lack of mechanisation of various farming operations (Dogra et al., 2008). Even today the farmers in the hilly regions of Uttarakhand use conventional methods like hand beating, animal feet trampling for 
threshing crops. All these processes are tiresome, time consuming and labor intensive. Threshing of pulse crops done by conventional threshers resulting in high seed damage and threshing losses (Sessiz and Poyraj, 2003). Because of the demand for a small multicrop thresher for hills is high, the existing cowpea thresher with multicrop potential shall be modified to suit other pulse crop such as black gram. Keeping in view the above facts, the study was carried out for modification and performance evaluation of thresher for black gram.

\section{Materials and Methods}

The existing axial flow thresher was developed in Department of Farm Machinery and Power Engineering at G.B Pant University. It consists of spike tooth type threshing cylinder of $600 \mathrm{~mm}$ diameter. The lower concave is made of M.S square bars of $6 \times 6 \mathrm{~mm}$ size with rectangular size of $25 \times 10$ $\mathrm{mm}$ in-between. An oscillating sieve having mesh diameter of $10 \mathrm{~mm}$ has been provided for cleaning purpose. An aspirator which has radial flow type fan of diameter $320 \mathrm{~mm}$ for removal of chaff and other foreign material.
Mild steel single groove pulley and V-belt has been used to transmit power from motor to thresher. Based on the preliminary trials conducted on thresher it was found that the aspirator design was necessary.

\section{Modification of aspirator}

Aspirator is essential part in the thresher which had a major role in cleaning efficiency. The aspirator was modified by shutter arrangement which is a half-moon shaped 230 $\mathrm{mm}$ diameter metal sheet which works as an aspirator eye so as to provide variable air velocity without changing the speed of thresher or any pulley. It is an essential requirement to change the suction force of the aspirator in case of the variation in crop moisture content. If the crop is dried more than the optimum, it will be light in weight. So there may be a chance for the aspirator suck out the light grains which is over dried. To prevent this problem the shutter can be opened such that it will reduce the suction force. Therefore one shutter had been provided at the entry side of the centrifugal aspirator. The view of aspirator assembly has shown in Plate 1.

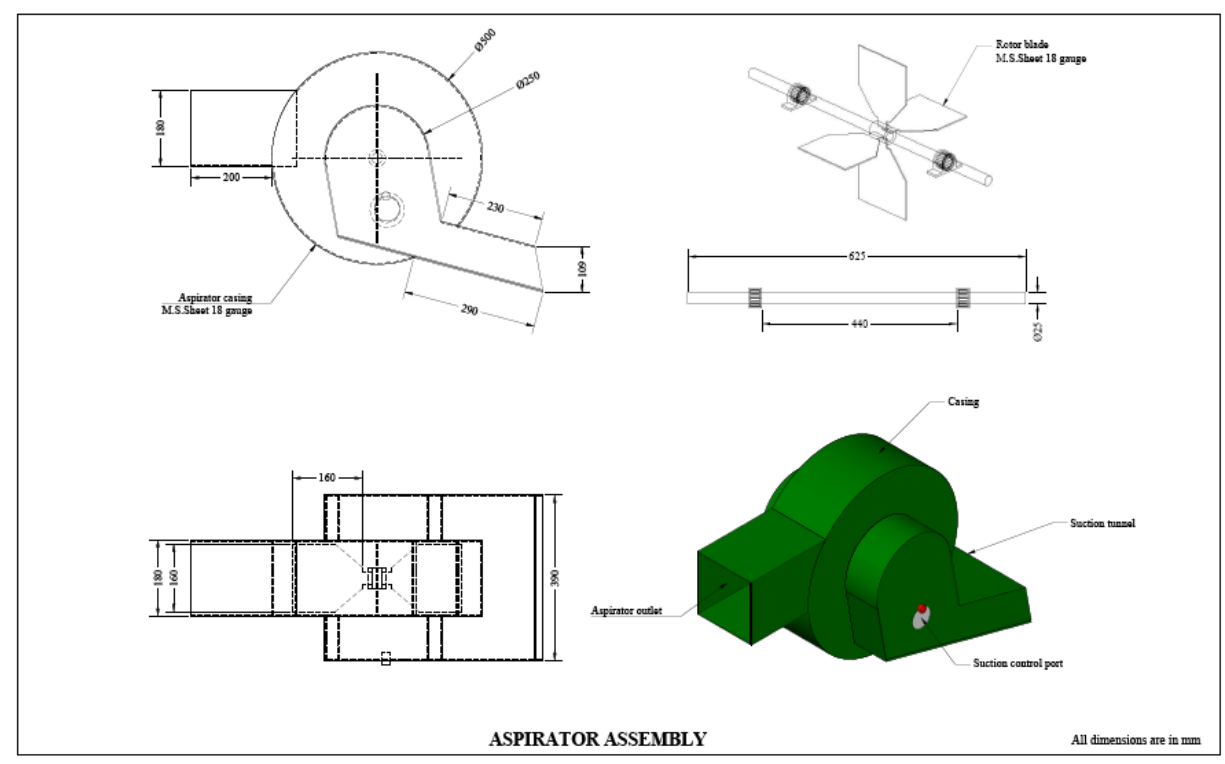

Plate.1 Aspirator Assembly 


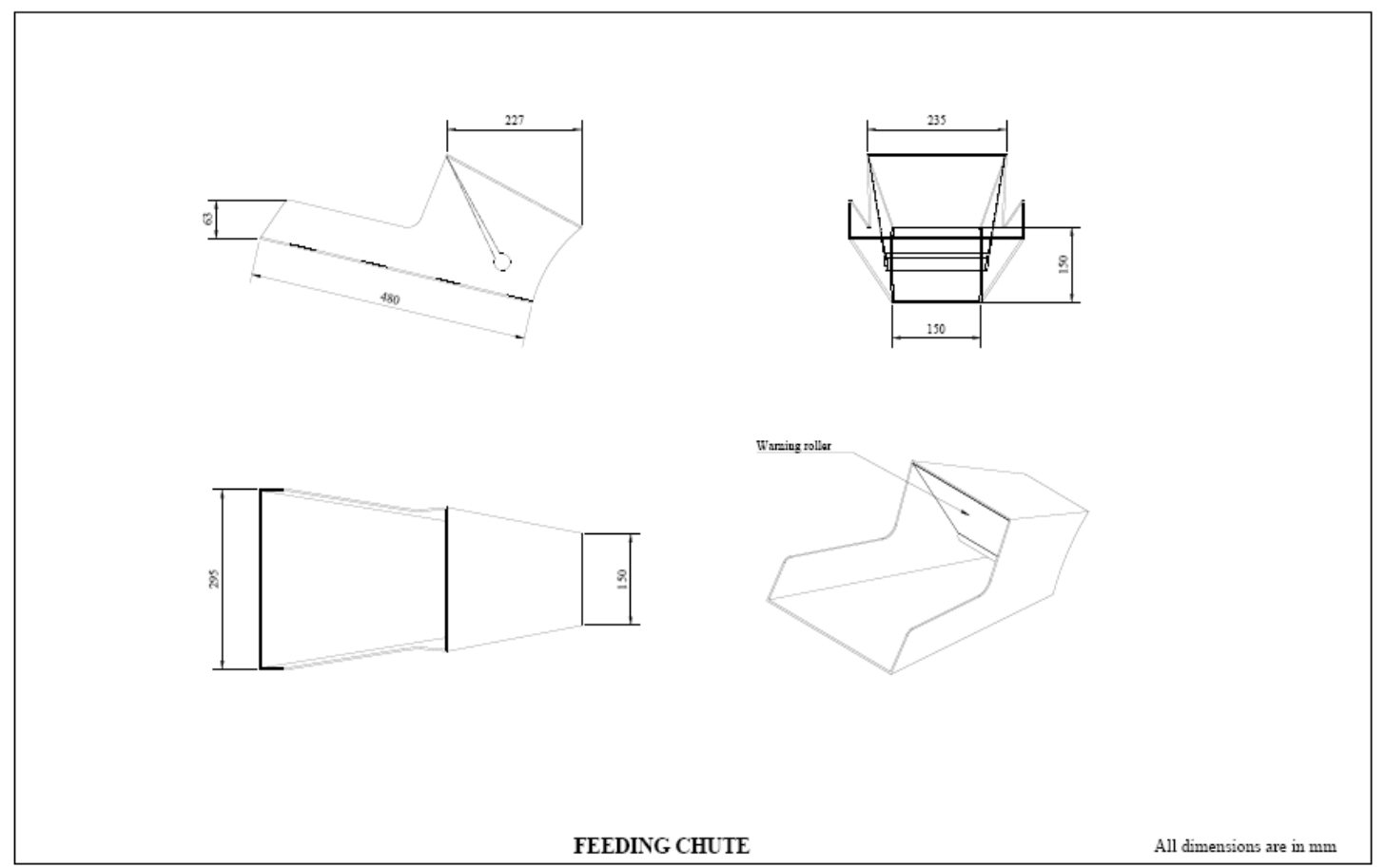

Plate.2 Different view of Feeding Chute

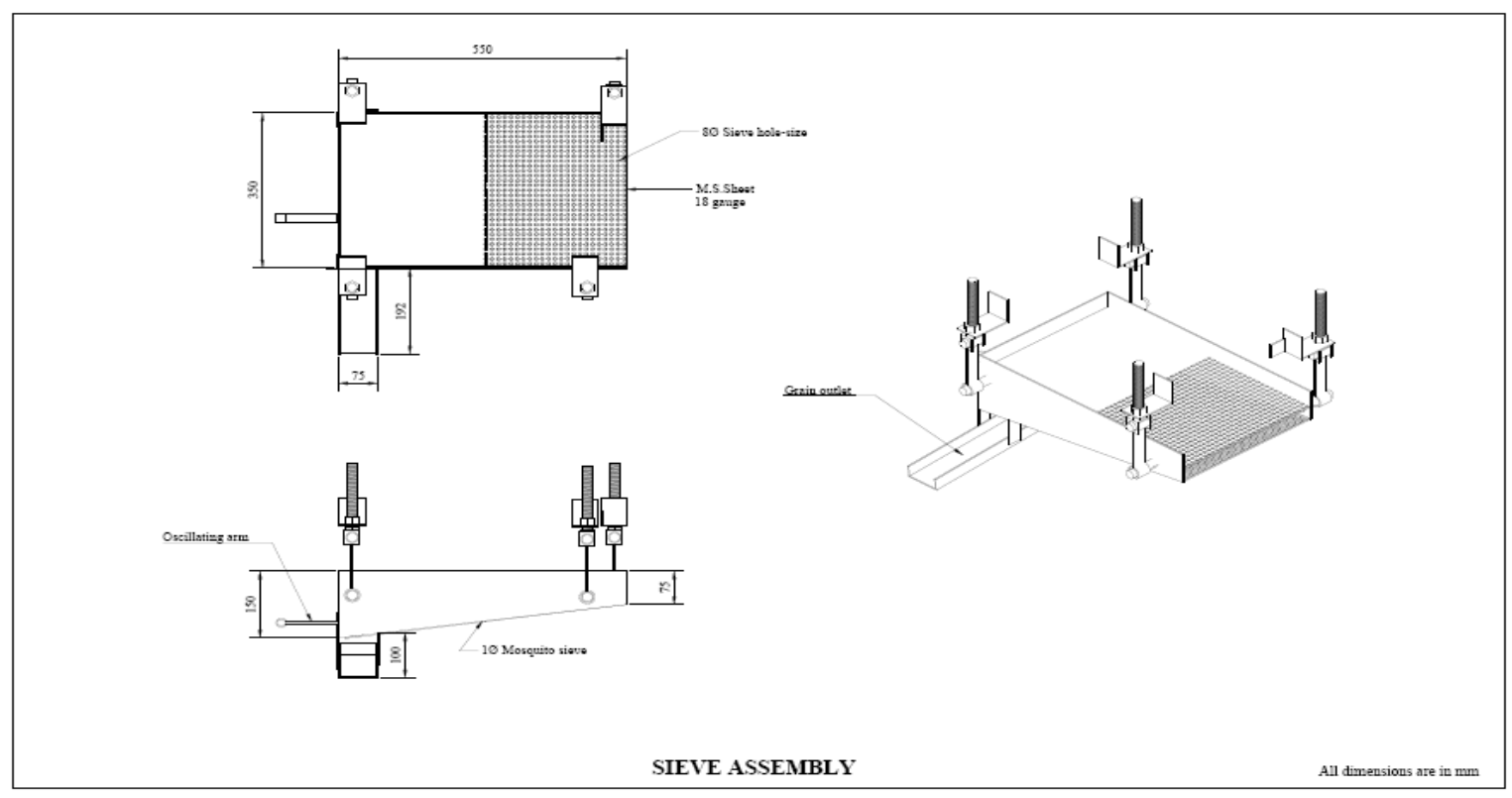

Plate.3 Different views of sieve assembly

\section{Feeding chute}

Dimensions of feeding chute were decided according to IS 9020:2002. According to BIS recommendation the total length of chute was taken was $450 \mathrm{~mm}$ and covered portion lenth taken as $225 \mathrm{~mm}$. Angle of lift for covered portion taken an $28^{\circ}$. To facilitate easy and smooth feeding of the crop during operation, the feeding chute mounted properly on the thresher. In the mounted positon, angle was $13^{\circ}$. The feeding chute fixed with the thresher which is impossible to remove easly and the covered portion of the chute shall not be able to be detadhed without cutting according the above mentioned IS code. Different views of feeding chute is shown in 


\section{Modification based on ergonomic design criteria}

On Indian farms threshers are used mainly for threshing of grains, but are causing in a significant proportion of limb injuries. International safety standards are somewhat difficult to impose as the manufacture of machines is done locally. These locally made machines are used for crop operations, with a great use of manual work. The machine was developed with improved design for safe operation of threshers based on principles of ergonomics. Thresher injuries have been reported increasing due to lack of safety and ergonomics by Kumar et al., (2002) recorded that this machine caused $2 \%$ of total agricultural injuries though their usage only for a few days in the year.

The factors considered for the improved design were work posture, chute design and entanglement of body parts into the auxiliary power transmission system of the thresher. A critical dimension which influences the outcome of whether an operator sustains injuries or not are chute parameters such as chute cover length and chute-opening height in case of feed chute is concerned. To have safer chute parameters, dimensions of forearm, arm length and waist height of Indian males were used. From the data it was clear that the $95^{\text {th }}$ percentile male forearm dimension was $418 \mathrm{~mm}$ and this dimension accounts for $95^{\text {th }}$ percentile Indian woman also. According to this feeding chute length was fixed as $450 \mathrm{~mm}$ at a height of $1100 \mathrm{~mm}$ from the operating platform especially ground. Based on coefficient of friction of grains, an inclination of $15-25^{\circ}$ is selected (Thyagaraj et al. ,1982). Based on this the chute tilt angle fixed at $20^{\circ}$ in order to fall small pieces of stocks in to drum on their own.

Depending up on the operator feed the thresher from the side or from the front, the thresher was designed in a way that if the operator feeds from the front, his hand wont able to touch the drum because the feeding chute will act as a barrier to the person when he tries to push the crop more in to the cylinder. The chute will prevent operator's waist and prevent his hand as he bends to reach the drum.

If the operator operates from the side of the feeding chute, it is provided with a hand warning roller at the end of hinged baffle which acts due to gravity. As the operator insert his hands to the chute and reaches up to the drum the roller touches his hand. This warns the operator to not push his hands further. It also gives protection from flying objects towards the operator.

Guards have been provided on all moving parts of the thresher to prevent accidental contact of persons or parts of clothing being caught. It was made of M.S mesh with thickness of $2 \mathrm{~mm}$. It is attached rigidly to machine for uneasy removal and also with the provision for servicing and adjustment without complete removal of guards (IS 9020:2002). In order to use the existing axial flow thresher for black gram, the following modifications were incorporated.

\section{Modifications of thresher for black gram Sieve}

The existing sieve used for the soybean was $10 \mathrm{~mm}$ diameter. During the preliminary testing of thresher for black gram crop, it was observed that large size stalk also passes through along with threshed grains. Therefore, it was found necessary to change the sieve size. Based on the grain size and sphericity of black gram crop $4.10 \mathrm{~mm}$ maximum and average sphericity of 0.81 a sieve of $5 \mathrm{~mm}$ mesh diameter was selected for black gram crop. It was observed that black gram grains were falling on the ground from the frame of oscillating sieve which leads to 
increase the sieve loss of the grains especially in higher speed range. The height of the frame was not sufficient to retain the grains. Therefore, the height of side frame was increased from $20 \mathrm{~mm}$ to $40 \mathrm{~mm}$. A M.S sheet of $3 \mathrm{~mm}$ thickness was welded on the existing frame so as to increase the sides up to required height. (Plate 3 ).

\section{Concave}

It was felt during preliminary testing of thresher on black gram crop that most of the pods remain unthreshed and also pass through the concave at various speeds ranging from 300 to $440 \mathrm{rpm}$. However, the quantity of unthreshed pods decreased with increase in speed. The poor threshing was due to the fact that insufficient hindrance was offered to the crop by the concave because of its larger grating. In order to increase the retention time of the crop on the concave, a M.S of $10 \mathrm{~mm}$ was welded over the concave in front of the crop inlet over $355 \mathrm{~mm}$ length, thresher was run again. It was found that this provision gave greater hindrance and resulted in higher grain damage even at low speed. The higher grain damage was due to the fact that the grains are rotating with the threshed crop for longer time as there was no opening in the blind portion of the lower concave to allow the material to pass freely through it. To overcome this problem, a M.S sheet was replaced with the perforated M.S sheet having $25 \times 6 \mathrm{~mm}$ rectangular openings so that threshed grain pass through the concave. This change provided sufficient hindrance to get the crop threshed.

\section{Sieve shaker}

It was observed that during the preliminary trial operation the thresher the threshed material was not able to pass through the primary sieve even though the sieve hole size adequate. This was due to higher oscillation of the sieve assembly. To improve the passing of grains through the primary sieve the oscillation of the sieve assembly were decreased by decreasing the radius of the crank from $35 \mathrm{~mm}$ to $30 \mathrm{~mm}$ so that the sieve oscillation reduced from 180 to 160 cycles /min.

\section{Performance Evaluation of Thresher}

The Parameters selected for study are shown in Table 1. Tests were conducted on one variety of black gram crop (Pant Urad-31) taken from Crop Research Center, Pantnagar. The thresher was operated with $1.49 \mathrm{~kW}$ motor. The feed rate was constant. Bundles of $3 \mathrm{~kg}$ were made for constant feeding and time was recorded using stopwatch. Feed rate fixe as $180 \mathrm{~kg} / \mathrm{h}$ based on the preliminary trails conducted.

The speed of electric motor was $1440 \mathrm{rpm}$ and $100 \mathrm{~mm}$ diameter pulley was attached to motor. The speed of aspirator was fixed at $1920 \mathrm{rpm}$ by using the pulley of diameter $76.20 \mathrm{~mm}$ air velocity was found to be $10 \mathrm{~m} / \mathrm{s}$ measured using anemometer. The cylinder speed was kept as $370 \mathrm{rpm}(7.16 \mathrm{~m} / \mathrm{s})$ by using pulley of diameter $380.1 \mathrm{~mm}$, and clearance between cylinder tip and concave was adjusted to $15 \mathrm{~mm}$. V- belt was used for connecting the two pulley. The stroke of oscillating sieve was found 160 cycles $/ \mathrm{min}$. The diameter of eccentric pulley was 203.2 $\mathrm{mm}$. The speeds of various rotating components were measured using tachometer having $0.99 \mathrm{rpm}$ range with a least count of $\pm 1 \mathrm{rpm}$. The speed of cylinder was measured for each of the treatments. For moisture content three samples were taken from the heap of crop and average was reported.

The thresher was operated with the same setting of soybean crop which is $370 \mathrm{rpm}$ $(7.16 \mathrm{~m} / \mathrm{s})$ cylinder speed and $15 \mathrm{~mm}$ concave clearance except the cleaning sieve size and 
grate size which was changed to increase the cleaning efficiency. An additional structure made from M.S flat $(25 \times 3) \mathrm{mm}$ and wire of 4 $\mathrm{mm}$ diameter was attached to lower concave so that its perforations was reduced to $6 \mathrm{~mm}$, earlier it was $10 \mathrm{~mm}$ so as to get fine straw. Sieve hole size of $5 \mathrm{~mm}$ were also used for the evaluation for improved cleaning. A chaff sample of about $1000 \mathrm{~g}$ was also taken from aspirator to study the grain loss.
Similarly, the experiments were conducted at $300 \mathrm{rpm}(5.8 \mathrm{~m} / \mathrm{s})$, and $440 \mathrm{rpm}(8.52 \mathrm{~m} / \mathrm{s})$ with adjusting the concave clearance 12, 15 and $18 \mathrm{~mm}$ and cylinder speed was changed by using the different sizes of pulley of 482.6 $\mathrm{mm}$ (19 inch), 330mm (13 inch), respectively. Experiments were repeated three times at each combination of the variables and average values were calculated and presented on percentage basis.

\begin{tabular}{|c|c|c|c|c|c|c|c|}
\hline \multicolumn{8}{|c|}{ Black Gram } \\
\hline \multicolumn{2}{|c|}{ Independent Variables } & \multicolumn{5}{|c|}{ Dependent Variables } & $\begin{array}{c}\text { Fixed } \\
\text { Parameter }\end{array}$ \\
\hline Cylinder Speed & $\begin{array}{l}\text { Conclave } \\
\text { Clearance }\end{array}$ & \multirow[t]{4}{*}{$\begin{array}{c}\text { Visible } \\
\text { Grain } \\
\text { Damage }\end{array}$} & \multirow[t]{4}{*}{$\begin{array}{c}\text { Germination } \\
\text { Percentage }\end{array}$} & Losses & \multirow[t]{4}{*}{$\begin{array}{l}\text { Threshing } \\
\text { Efficiency }\end{array}$} & \multirow[t]{4}{*}{$\begin{array}{l}\text { Cleaning } \\
\text { Efficiency }\end{array}$} & $\begin{array}{l}\text { Moisture } \\
\text { Content }\end{array}$ \\
\hline $\begin{array}{c}\mathrm{N} 1320 \mathrm{rpm} \\
(6.19 \mathrm{~m} / \mathrm{s})\end{array}$ & $\begin{array}{c}\mathrm{C}_{1} \\
(12 \mathrm{~mm}) \\
\end{array}$ & & & \multirow{3}{*}{$\begin{array}{l}\text { 1.Sieve Loss } \\
\text { 2.Cylinder } \\
\text { Loss } \\
\text { 3.Blower Loss }\end{array}$} & & & \multirow{3}{*}{ Feed Rate } \\
\hline $\begin{array}{c}\mathrm{N} 2370 \mathrm{rpm} \\
(7.16 \mathrm{~m} / \mathrm{s})\end{array}$ & $\begin{array}{c}\mathrm{C}_{2} \\
(15 \mathrm{~mm})\end{array}$ & & & & & & \\
\hline $\begin{array}{c}\text { N3 } 440 \mathrm{rpm} \\
(8.52 \mathrm{~m} / \mathrm{s})\end{array}$ & $\begin{array}{c}\mathrm{C}_{3} \\
(18 \mathrm{~mm})\end{array}$ & & & & & & \\
\hline
\end{tabular}

Table.1 Parameter selected for study

\section{Results and Discussion}

The effect and accuracy of modification was checked on the basis of performance and evaluation of the thresher. The different views of the modified thresher is shown in the Plate 4.

\section{Performance Evaluation of Thresher on Black gram Crop}

To evaluate the performance of thresher the black gram variety pant urad-31 was used. The effect of cylinder speed and cylinderconcave clearance on dependent variable viz. threshing efficiency, cleaning efficiency, visible grain damage, losses and germination percentage were studied. The average moisture content of the crop was $12.8 \%$ on dry basis. As moisture content increases from 7 to $13 \%$ damaged seed decreased from 92.8 to $90.4 \%$ (Saiedirad et al., 2011).
Effect of cylinder speed and cylinder-

The relationship between threshing efficiency and cylinder speed in accordance with the variation of cylinder concave clearance is shown in Fig. 1. It was evident from the figure and the Table 2 that the threshing efficiency increases linearly with the increase in cylinder speed for every concave clearance. The increase in threshing efficiency was found due to the fact that at higher speeds the impact energy imparted by the cylinder to the crop is more. It may be seen from the figure that threshing efficiency varied from 98.19 to $99.87 \%$ at $12 \mathrm{~mm}$ concave clearance while it varied from 98.91 to $98.96 \%$ at $15 \mathrm{~mm}$ concave clearance whereas threshing efficiency varied between 96.48 to $97.14 \%$ at $18 \mathrm{~mm}$ concave clearance. The maximum threshing efficiency of $99.87 \%$ was observed at $440 \mathrm{rpm}(8.52 \mathrm{~m} / \mathrm{s})$ cylinder speed and 12 
mm concave clearance whereas the minimum of $96.48 \%$ was found at $300 \mathrm{rpm}(5.80 \mathrm{~m} / \mathrm{s})$ at $18 \mathrm{~mm}$ concave clearance. Results obtained showed a similar trend that high threshing efficiency obtained at low clearances (Omran, 2005).

It is also clear from Fig. 1 that threshing efficiency was found low at $18 \mathrm{~mm}$ concave clearance at each cylinder speed. This was because of the fact that at higher concave clearance the pods were getting detached from the crop just after entering the cylinder and simultaneously passing through the concave without being threshed properly. This problem was not encountered at lower concave clearance and resulting in better threshing efficiency. Statistical analysis of cylinder speed and cylinder-concave clearance as shown in Table C-8 indicates that the effect of cylinder speed, cylinder-concave clearance was significant $(\mathrm{P}<0.05)$.

\section{Effect of cylinder speed and cylinder- concave clearance on cleaning efficiency}

The relationships of cleaning efficiency versus cylinder speed at three different concave clearances are given in Fig.1 and their respective data are presented in Table 2. The data shows that cleaning efficiency increases very slightly with increase in cylinder speed for all concave clearances. As the cylinder speed increases, the speed of sieve oscillation increases which in turn decreases the accumulation of the stalk and grain particles on the sieve. When the sieve oscillation increases the grain will easily pass through the sieve causing the remaining straw will be easily sucked up by the aspirator. At higher concave clearances, the stalk were not broken into smaller pieces, some of which were passing through the oscillatory sieve along with grains and hence resulted in poor cleaning. At lower concave clearance the cleaning efficiency remain almost constant and the above problem was substantially minimized. But at the lower concave clearance the cleaning efficiency also remained less because the stalk was broken into very small pieces and it would pass through the lower concave instead of cylinder outlet. So more straw and grain start to accumulate over the sieve for a fraction of time and the aspirator did not have sufficient time to suck up all the straw which leads to some straw passing through the sieve and causing poor cleaning efficiency.

Maximum cleaning efficiency of $98.42 \%$ was achieved at $370 \mathrm{rpm}(7.16 \mathrm{~m} / \mathrm{s})$ at $15 \mathrm{~mm}$ concave clearance and minimum cleaning of $97.12 \%$ observed at $440 \mathrm{rpm}(8.52 \mathrm{~m} / \mathrm{s})$ at 18 $\mathrm{mm}$ concave clearance. Statistical analysis of data shows that cylinder speed and concave clearance has no significant effect on cleaning efficiency on these variable ranges.

\section{Effect of cylinder speed and cylinder- concave clearance on different losses}

Effect of cylinder speed and cylinder-concave clearance on different losses was observed.

The different losses namely sieve loss, cylinder loss and blower loss at different cylinder speed and different cylinder-concave clearance is given in Table 3 and their relationship is shown in Fig. 2. Variation in different losses is discussed below:

\section{Cylinder loss}

When cylinder loss is taken into consideration cylinder speed is an important parameter to be considered. The data regarding the cylinder loss at different cylinder speed and concave clearances are represented in Table 3. It was observed that when cylinder speed increased, less cylinder loss occurred because of the reason that less unthreshed grains were received at the cylinder outlet at higher 
cylinder speed. At each concave clearances similar phenomena was observed that the cylinder loss decreased with increase in cylinder speeds with respective concave clearances.

The cylinder loss ranged from 0.37 to $0.48 \%$. The minimum cylinder loss of $0.37 \%$ was found at cylinder speed of $440 \mathrm{rpm}(8.52 \mathrm{~m} / \mathrm{s})$ with $18 \mathrm{~mm}$ cylinder concave clearance. The maximum loss of $0.48 \%$ was also observed at same cylinder speed and cylinder-concave clearance. Statistically there is significant effect $(\mathrm{P}<0.05)$ of cylinder speed and no significant effect of cylinder-concave clearance on cylinder loss.

\section{Blower loss}

It is seen from Fig.4.6 the effect of cylinder speeds and cylinder-concave clearances on blower loss. It was observed from the graph that when cylinder speed increases the blower loss also increases. It was because at higher cylinder speed more breakage occurs and broken grains were sucked by suction tunnel of aspirator assembly. When the concave clearance was decreased and cylinder speed was increased the breakage of the grain was increased which in turn increased the blower loss. The minimum loss of $3.22 \%$ was found at cylinder speed of $440 \mathrm{rpm}(8.52 \mathrm{~m} / \mathrm{s})$ with $18 \mathrm{~mm}$ cylinder-concave clearance whereas the maximum loss of $4.56 \%$ was noted at cylinder speed of $440 \mathrm{rpm}(8.52 \mathrm{~m} / \mathrm{s})$ with 12 $\mathrm{mm}$ concave clearance. It was observed from the graph that the effect of cylinder speed is major as compared to the effect of concave clearance on blower loss. When the cylinder speed was increased there was a considerable change in the blower loss. The maximum blower loss was observed at maximum cylinder speed. Statistical analysis that the effect of cylinder speed and concave clearance. From that table it has been inferred that the cylinder speed has significant $(\mathrm{P}<0.05)$ effect on blower loss.

\section{Sieve loss}

In general, the sieve loss increased with the increase in cylinder speed which was caused by the proportional increase in the speed of eccentric which in turn increases oscillation on the cleaning sieves as observed from Fig. 3. This caused the grain to spill over the sieve. It is also clear from the figure that concave clearance has no major role in the sieve loss. The sieve loss varied from 0.31 to $0.37 \%$ for different combinations of cylinder speed and cylinder-concave clearance. The minimum loss $0.31 \%$ was observed on cylinder speed of $300 \mathrm{rpm}(5.80 \mathrm{~m} / \mathrm{s})$ with concave clearance of $15 \mathrm{~mm}$ and maximum loss was observed at cylinder speed of $440 \mathrm{rpm}(8.52 \mathrm{~m} / \mathrm{s})$ with concave clearance $12 \mathrm{~mm}$. The data regarding the sieve loss has been represented in Table 3 .

Statistical analysis of the data showed that there is significant effect $(\mathrm{P}<0.05)$ of cylinder speed on sieve loss while the concave clearance and interaction has no significant effect.

The thresher total loss is represented in Table 4. The total loss varies from 4.24 to $5.33 \%$. Maximum grain loss was observed in the combination of cylinder speed $440 \mathrm{rpm}(8.52$ $\mathrm{m} / \mathrm{s}$ ) with concave clearance of $12 \mathrm{~mm}$ whereas the minimum loss occurred in the combination of cylinder speed of $300 \mathrm{rpm}$ $(5.80 \mathrm{~m} / \mathrm{s})$ and concave clearance of $15 \mathrm{~mm}$. As per the BIS standard the total loss should be less than $5 \%$. The thresher performance was in accordance with the BIS standard except in two combinations (370 and $440 \mathrm{rpm}$ at $12 \mathrm{~mm}$ concave clearance).

\section{Effect of cylinder speed and cylinder- concave clearance on visible grain damage}

Grain damage was influenced by cylinder speed and concave clearance. As presented in Table 5 the results revealed that the breakage 
percentage increased slightly with increase in cylinder speed while it increased with decrease in concave clearance. More grain damage was observed at higher speed. The reasons for excessive seed damage at higher cylinder speed could be more impact prone threshing, frictional and rubbing forces, which resulted in more breakage.

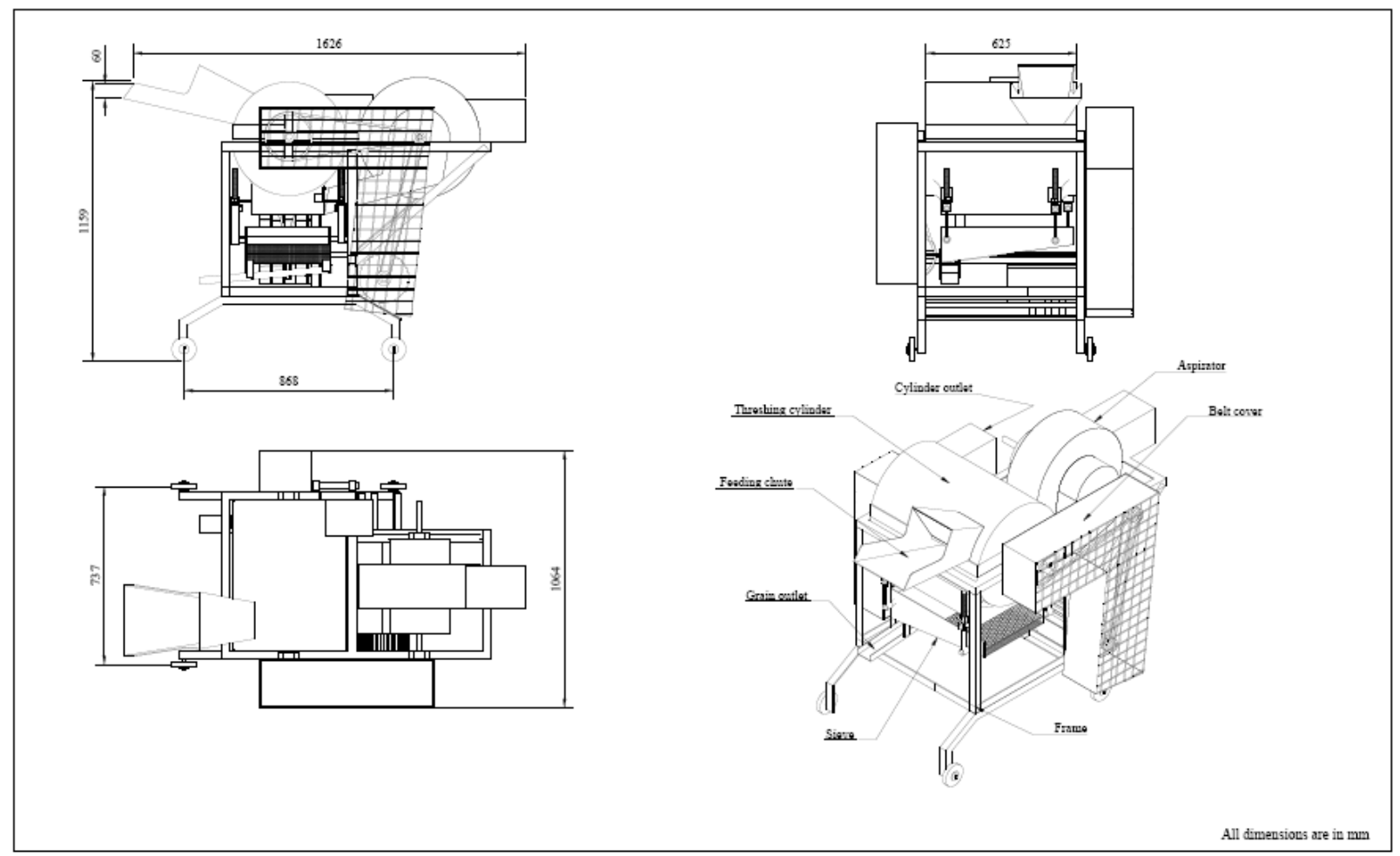

Plate.4 Different views of modified Thresher

Table.2 Threshing efficiency and cleaning efficiency at different cylinder speeds and concave clearances and concave clearances of black gram crop

\begin{tabular}{|c|c|c|c|c|c|}
\hline $\begin{array}{c}\text { Sl. } \\
\text { No }\end{array}$ & $\begin{array}{c}\text { Treatment } \\
\text { combination }\end{array}$ & $\begin{array}{c}\text { Cylinder } \\
\text { speed (rpm) }\end{array}$ & $\begin{array}{c}\text { Concave } \\
\text { clearance (mm) }\end{array}$ & $\begin{array}{c}\text { Threshing } \\
\text { efficiency (\%) }\end{array}$ & $\begin{array}{c}\text { Cleaning } \\
\text { efficiency } \mathbf{( \% )}\end{array}$ \\
\hline $\mathbf{1}$ & $\mathrm{C}_{1} \mathrm{~N}_{1}$ & 300 & 12 & 98.19 & 97.57 \\
\hline $\mathbf{2}$ & $\mathrm{C}_{1} \mathrm{~N}_{2}$ & 370 & 12 & 98.24 & 97.64 \\
\hline $\mathbf{3}$ & $\mathrm{C}_{1} \mathrm{~N}_{3}$ & 440 & 12 & 99.87 & 97.65 \\
\hline $\mathbf{4}$ & $\mathrm{C}_{2} \mathrm{~N}_{1}$ & 300 & 15 & 98.91 & 97.71 \\
\hline $\mathbf{5}$ & $\mathrm{C}_{2} \mathrm{~N}_{2}$ & 370 & 15 & 98.94 & 98.69 \\
\hline $\mathbf{6}$ & $\mathrm{C}_{2} \mathrm{~N}_{3}$ & 440 & 15 & 98.96 & 98.21 \\
\hline $\mathbf{7}$ & $\mathrm{C}_{3} \mathrm{~N}_{1}$ & 300 & 18 & 96.48 & 97.12 \\
\hline $\mathbf{8}$ & $\mathrm{C}_{3} \mathrm{~N}_{2}$ & 370 & 18 & 96.86 & 97.78 \\
\hline $\mathbf{9}$ & $\mathrm{C}_{3} \mathrm{~N}_{3}$ & 440 & 18 & 97.14 & 98.10 \\
\hline
\end{tabular}



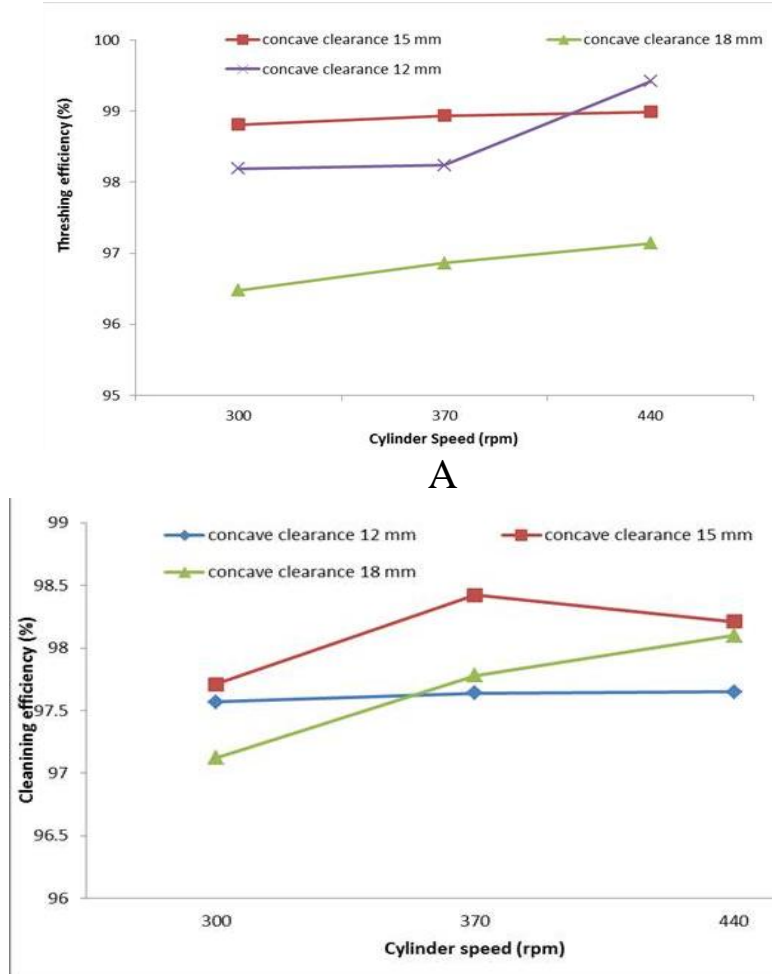

B

Fig.1 Effect of cylinder speed and cylinder concave clearance on (A) threshing efficiency and (B) cleaning efficiency in black gram crop

Table.3 Thresher losses at different cylinder speeds and concave clearances of black gram crop

\begin{tabular}{|c|c|c|c|c|c|c|}
\hline $\begin{array}{c}\text { Sl. } \\
\text { No }\end{array}$ & $\begin{array}{c}\text { Treatment } \\
\text { combination }\end{array}$ & $\begin{array}{c}\text { Cylinder } \\
\text { speed } \\
(\mathbf{r p m})\end{array}$ & $\begin{array}{c}\text { Concave } \\
\text { clearance }(\mathbf{m m})\end{array}$ & $\begin{array}{c}\text { Thlinder loss } \\
\mathbf{( \% )}\end{array}$ & $\begin{array}{c}\text { Blower } \\
\text { loss }(\boldsymbol{\%})\end{array}$ & $\begin{array}{c}\text { Sieve } \\
\text { loss }(\mathbf{\%})\end{array}$ \\
\hline $\mathbf{1}$ & $\mathrm{C}_{1} \mathrm{~N}_{1}$ & 300 & 12 & 0.44 & 3.95 & 0.32 \\
\hline $\mathbf{2}$ & $\mathrm{C}_{1} \mathrm{~N}_{2}$ & 370 & 12 & 0.41 & 4.44 & 0.36 \\
\hline $\mathbf{3}$ & $\mathrm{C}_{1} \mathrm{~N}_{3}$ & 440 & 12 & 0.40 & 4.56 & 0.37 \\
\hline $\mathbf{4}$ & $\mathrm{C}_{2} \mathrm{~N}_{1}$ & 300 & 15 & 0.46 & 3.96 & 0.31 \\
\hline $\mathbf{5}$ & $\mathrm{C}_{2} \mathrm{~N}_{2}$ & 370 & 15 & 0.41 & 3.91 & 0.34 \\
\hline $\mathbf{6}$ & $\mathrm{C}_{2} \mathrm{~N}_{3}$ & 440 & 15 & 0.38 & 3.98 & 0.33 \\
\hline $\mathbf{7}$ & $\mathrm{C}_{3} \mathrm{~N}_{1}$ & 300 & 18 & 0.48 & 3.44 & 0.32 \\
\hline $\mathbf{8}$ & $\mathrm{C}_{3} \mathrm{~N}_{2}$ & 370 & 18 & 0.40 & 3.93 & 0.34 \\
\hline $\mathbf{9}$ & $\mathrm{C}_{3} \mathrm{~N}_{3}$ & 440 & 18 & 0.37 & 3.7 & 0.34 \\
\hline
\end{tabular}


Int.J.Curr.Microbiol.App.Sci (2020) 9(3): 3213-3227
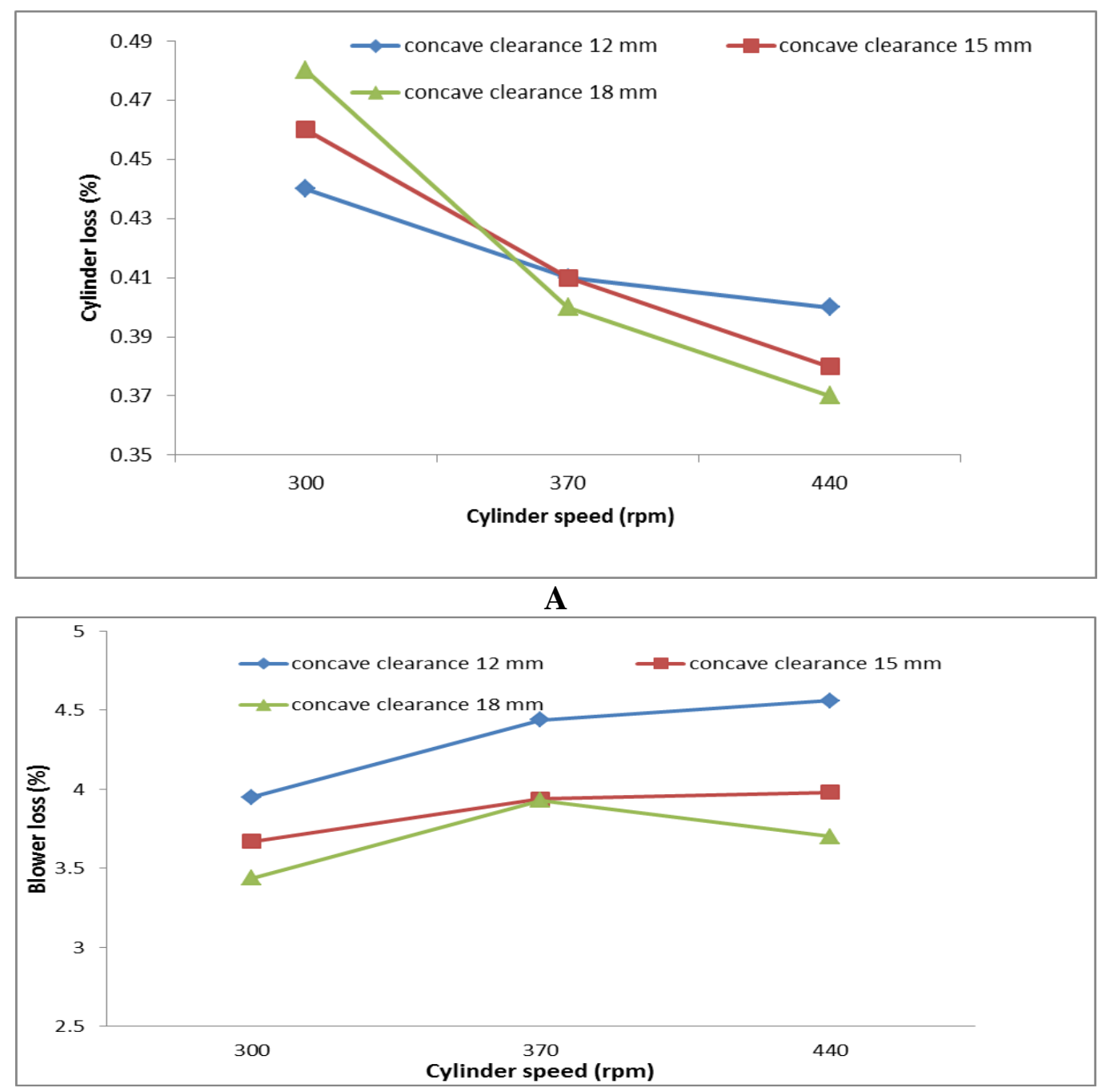

B

Fig.2 Effect of cylinder speed and cylinder concave clearance on (A) cylinder loss and (B) Blower loss in black gram crop

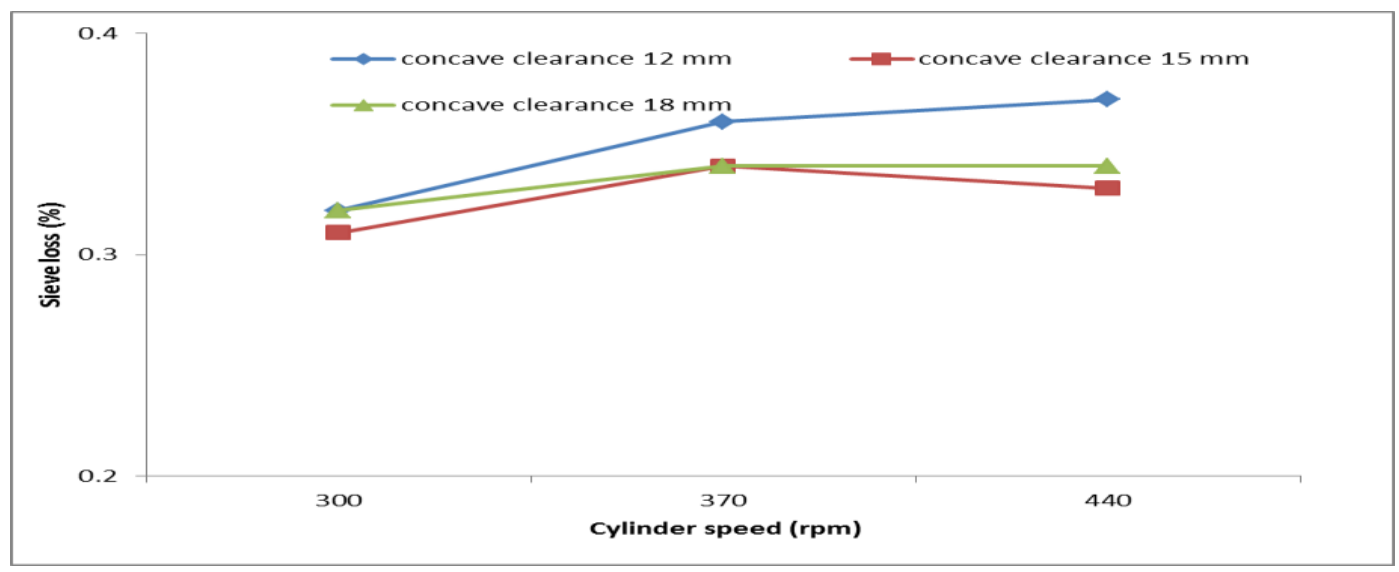

Fig.3 Effect of cylinder speed and cylinder concave clearance on sieve loss in black gram crop 
Int.J.Curr.Microbiol.App.Sci (2020) 9(3): 3213-3227

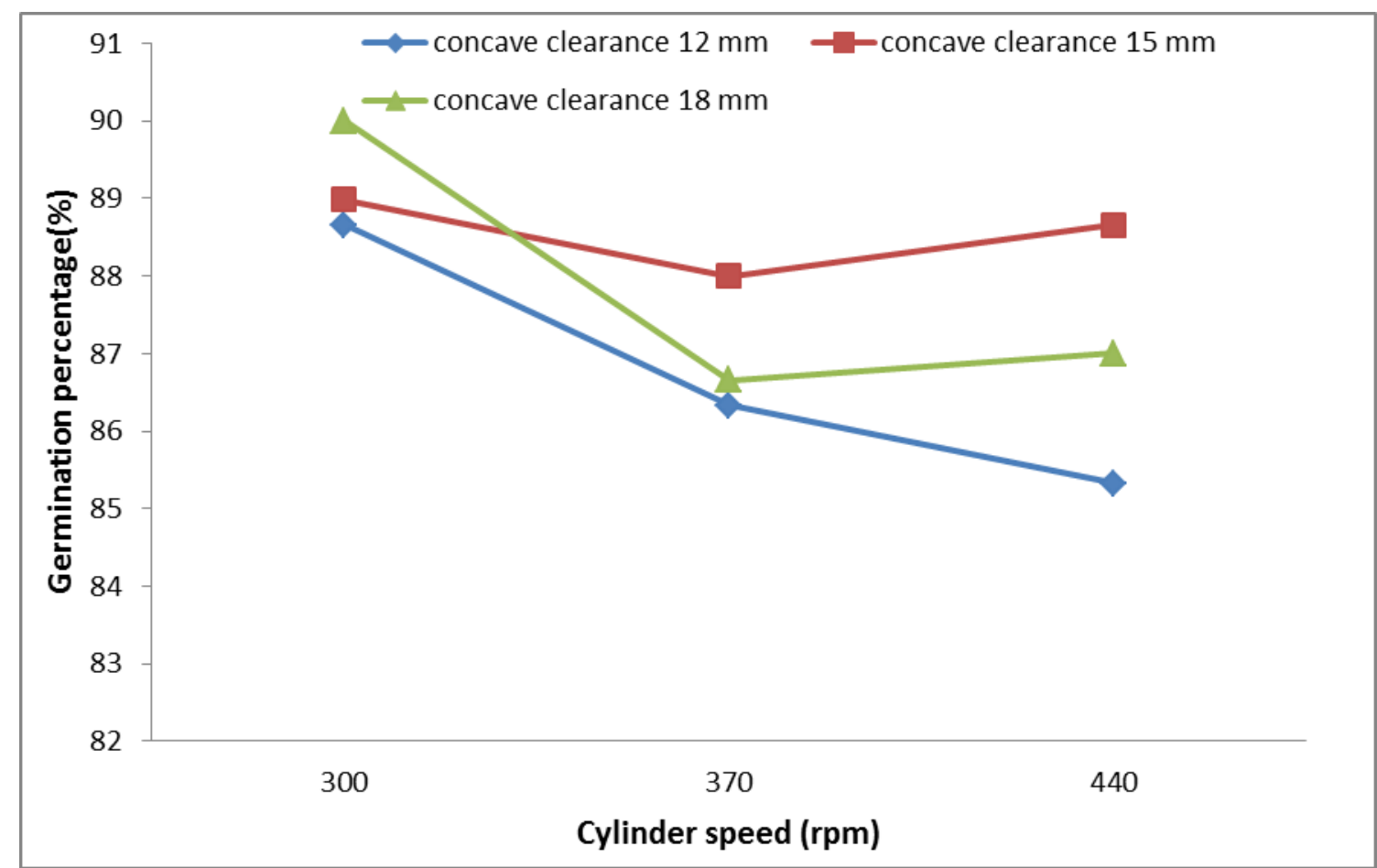

A

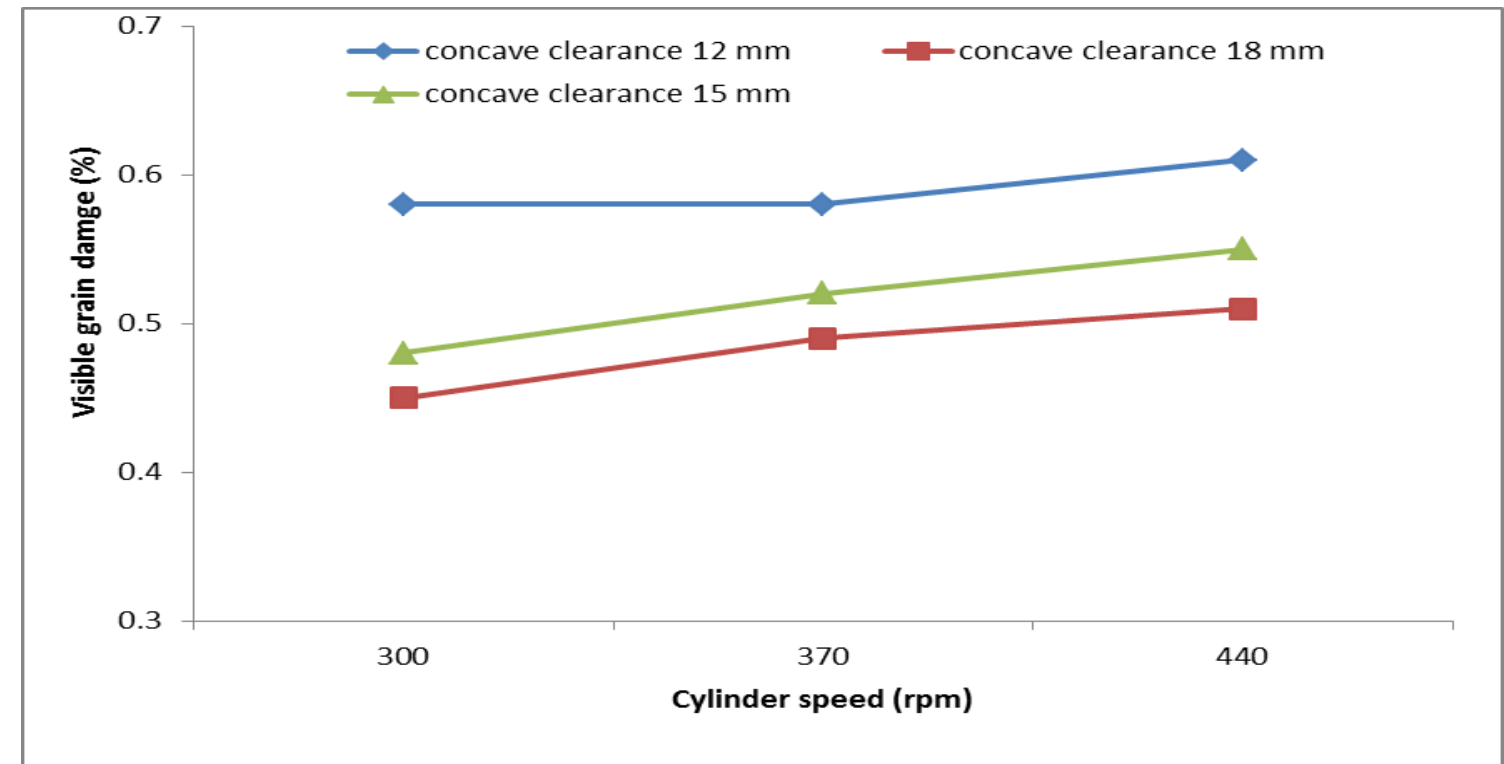

B

Fig.4 Effect of cylinder speed and cylinder concave clearance on (A) germination percentage and (B) visible grain damage in black gram crop 
Table.4 Total loss of thresher at different cylinder speed and concave clearances of black gram crop

\begin{tabular}{|c|c|c|c|c|}
\hline $\begin{array}{c}\text { S. } \\
\text { No }\end{array}$ & $\begin{array}{c}\text { Treatment } \\
\text { combination }\end{array}$ & $\begin{array}{c}\text { Concave clearance } \\
(\mathbf{m m})\end{array}$ & $\begin{array}{c}\text { Cylinder speed } \\
(\mathbf{r p m})\end{array}$ & Total loss (\%) \\
\hline $\mathbf{1}$ & $\mathrm{C}_{1} \mathrm{~N}_{1}$ & 12 & 300 & 4.71 \\
\hline $\mathbf{2}$ & $\mathrm{C}_{1} \mathrm{~N}_{2}$ & 12 & 370 & 5.21 \\
\hline $\mathbf{3}$ & $\mathrm{C}_{1} \mathrm{~N}_{3}$ & 12 & 440 & 5.33 \\
\hline $\mathbf{4}$ & $\mathrm{C}_{2} \mathrm{~N}_{1}$ & 15 & 300 & 4.73 \\
\hline $\mathbf{5}$ & $\mathrm{C}_{2} \mathrm{~N}_{2}$ & 15 & 370 & 4.66 \\
\hline $\mathbf{6}$ & $\mathrm{C}_{2} \mathrm{~N}_{3}$ & 15 & 440 & 4.69 \\
\hline $\mathbf{7}$ & $\mathrm{C}_{3} \mathrm{~N}_{1}$ & 18 & 300 & 4.24 \\
\hline $\mathbf{8}$ & $\mathrm{C}_{3} \mathrm{~N}_{2}$ & 18 & 370 & 4.67 \\
\hline $\mathbf{9}$ & $\mathrm{C}_{3} \mathrm{~N}_{3}$ & 18 & 440 & 4.41 \\
\hline
\end{tabular}

Table.5 Visible grain damage and germination percentage at different cylinder speeds and concave clearances of black gram crop

\begin{tabular}{|c|c|c|c|c|c|}
\hline $\begin{array}{c}\text { Sl. } \\
\text { No }\end{array}$ & $\begin{array}{c}\text { Treatment } \\
\text { combination }\end{array}$ & $\begin{array}{c}\text { Cylinder } \\
\text { speed (rpm) }\end{array}$ & $\begin{array}{c}\text { Concave } \\
\text { clearance (mm) }\end{array}$ & $\begin{array}{c}\text { Visible } \\
\text { grain } \\
\text { damage (\%) }\end{array}$ & $\begin{array}{c}\text { Germination } \\
\text { Percentage (\%) }\end{array}$ \\
\hline $\mathbf{1}$ & $\mathrm{C}_{1} \mathrm{~N}_{1}$ & 300 & 12 & 0.58 & 88.66 \\
\hline $\mathbf{2}$ & $\mathrm{C}_{1} \mathrm{~N}_{2}$ & 370 & 12 & 0.58 & 86.33 \\
\hline $\mathbf{3}$ & $\mathrm{C}_{1} \mathrm{~N}_{3}$ & 440 & 12 & 0.61 & 85.33 \\
\hline $\mathbf{4}$ & $\mathrm{C}_{2} \mathrm{~N}_{1}$ & 300 & 15 & 0.48 & 87.66 \\
\hline $\mathbf{5}$ & $\mathrm{C}_{2} \mathrm{~N}_{2}$ & 370 & 15 & 0.52 & 88.00 \\
\hline $\mathbf{6}$ & $\mathrm{C}_{2} \mathrm{~N}_{3}$ & 440 & 15 & 0.55 & 88.66 \\
\hline $\mathbf{7}$ & $\mathrm{C}_{3} \mathrm{~N}_{1}$ & 300 & 18 & 0.45 & 90.00 \\
\hline $\mathbf{8}$ & $\mathrm{C}_{3} \mathrm{~N}_{2}$ & 370 & 18 & 0.49 & 86.66 \\
\hline $\mathbf{9}$ & $\mathrm{C}_{3} \mathrm{~N}_{3}$ & 440 & 18 & 0.51 & 87.00 \\
\hline
\end{tabular}

The effect of increase in grain damage is not clearly expressed in graphical representation because of the fact that the grain damage is calculated from the main grain outlet and when cylinder speed increase causes more grain damage all the broken grain is sucked up by the aspirator before it reached the main grain outlet. So very less part of the broken grain is passed to the main grain outlet. And it may also be due the characteristics of crop which allows the grain to deform without any visible damage. The results confirmed with the findings ( Singhal and Thierstein 1987). (Sudjan and Salokhe 2002) also reported that seed damage increased with increase in cylinder speed and feed rates.

The maximum grain damage of $0.61 \%$ 
occurred in a combination of cylinder speed of $440 \mathrm{rpm}(8.52 \mathrm{~m} / \mathrm{s})$ and concave clearance of $12 \mathrm{~mm}$ whereas the minimum grain damage observed in the combination of cylinder speed of $300 \mathrm{rpm}(5.80 \mathrm{~m} / \mathrm{s})$ at concave clearance of $18 \mathrm{~mm}$. The results obtained are in accordance with the data reported by Neeraj et al.,1985.

Statistical analysis shows that the effect of cylinder speed and cylinder-concave clearance on visible grain damage was nonsignificant in these ranges of variable values.

\section{Effect of cylinder speed and cylinder- concave clearance on germination percentage}

Germination tests of various samples obtained during experiment were conducted and their data are represented in Table 5. Fig. 4 shows the relationship between germination percentage and cylinder speed at different levels of concave clearances. The germination percentage was found to decrease linearly with increase in cylinder speed irrespective of the concave clearance. On higher cylinder speed, the internal as well as external mechanical damage to the grains were expected to be more which caused low germination.

The germination percentage varied from 85.33 to $90 \%$. The maximum germination was obtained in combination of cylinder speed of $300 \mathrm{rpm}(5.80 \mathrm{~m} / \mathrm{s})$ with concave clearance of $18 \mathrm{~mm}$. Whereas the minimum germination occurred in a combination of cylinder speed $440 \mathrm{rpm}(8.52 \mathrm{~m} / \mathrm{s})$ and concave clearance of $12 \mathrm{~mm}$. Statistical analysis shows that the effect of cylinder speed and cylinder-concave clearance on visible grain damage was non-significant in these ranges of variable values.

From the above results it is seen that the overall germination percentage of the black gram crop variety pant-urad 31 by mechanical threshing was below $90 \%$. To check the viability of a seed germination test was also conducted of the grain which is threshed by manual means. And it was found that average value of the manually threshed black gram crop was $92 \%$. So it can be conclude that the poor germination percentage of black gram crop is not due the mechanical threshing but it was due to the poor viability of the seed variety and the condition of crop at the time of experiment.

It is clear from the results that the existing cowpea thresher was modified successfully and the obtained results after the performance evaluation showed that the modified thresher can be used in the hilly area for black gram threshing.

\section{References}

Indian Standard Codes. 9020: 2002 Safety requirements of power thresher

Kumar, A.; Mohan Dinesh, Patel Rajesh, Methew Varghese. 2002. Developed a grain threshers based on ergonomic design criteria. Journal of Applied Ergonomics. 33:503-508

Dogra, B., \& Ahuja, S. S. 2008. Performance evaluation of commercial wheat thresher on mungbean (Vigna radiata (L.) Wilczek). Journal of Research, 45: 62-66.

Neeraj. 1985. Performance evaluation of pigeon pea threshing methods. Thesis, M.Tech. G.B.P.U.A. \&T Pantnagar (UK), India.

Omran Musa Abbhss. 2005. Modification and performance of multicrop thresher. Journal of Science and Technology, 6(2):7-10.

Saiedirad M.H., 2011. A. Study on machinecrop parameters of cylinder threshers for cumin threshing. Agricultural 
Engineering International: CIGR Sudjan S; Salokhe V M. 2002. Effect of type Journal. Manuscript No.1746. of drum, drum speed and feed rates of Sessiz Abdullaah; Poyraz Ulger. 2003. Determination of threshing losses with a rasp bar type axial flow threshing unit. $J$ Agric. Engng, 40(4): 1-8.

SinghalO P; Tbierstein G E. 1987. Development of an axial flow thresher with multi-crop potential. Agricultural Mechanization in Asia, Africa and Latin sunflower threshing. Biosystem Engng, 83(4): 41 3-421. America, 18 (3): 57-65.

Thyagraj, C.R., Srivastava, N.S.L., 1982. Studies on the performance of improved feeding chute of threshers in relation to safety, feed rate and angel of inclination. J. Agric. Eng. 15 (1): 1923.

\section{How to cite this article:}

Nishanth M. Stanly, Arun Kumar, Ratnakiran D Wankhade, Pankaj Malkani, Annu Rani1 and Ekta Sharma. 2020. Modification and Performance Evaluation of Thresher for Black Gram. Int.J.Curr.Microbiol.App.Sci. 9(03): 3213-3227. doi: https://doi.org/10.20546/ijcmas.2020.903.368 